\title{
PENGARUH PENDIDIKAN GIZI DENGAN POSTER DAN KARTU GIZI TERHADAP PENINGKATAN PENGETAHUAN DAN SIKAP ANAK TENTANG GIZI SEIMBANG DI SDN PLOSO I-172 SURABAYA.
}

\section{THE EFFECTS OF NUTRITION EDUCATION WITH POSTER AND NUTRITION CARD \\ TO INCREASE CHILDREN'S KNOWLEDGE AND ATTITUDE OF BALANCED NUTRITION AT SDN PLOSO I-172 SURABAYA}

\author{
Sonya Hayu Indraswari \\ Departemen Gizi Kesehatan, \\ Fakultas Kesehatan Masyarakat, Universitas Airlangga, Surabaya, Indonesia \\ Alamat Korespondesni: Sonya Hayu Indraswari \\ E-mail: sonyahayuindraswari@gmail.com
}

\begin{abstract}
:
The prevalence of childhood obesity in Indonesia increase from year to year. This circumstance is believed to be associated with the high consumption of fatty foods and lack of knowledge of a balanced diet. Conducting the nutrition education of balance diet (nutrition counseling) is one of the ways to improve knowledge and attitude towards nutrition and to reduce nutritional problems. The study aims to analyze the effect of nutrition education by utilizing the poster and nutrition card on elementary students at SDN Ploso I-172 Surabaya. This study was Quasiexperimental research with pre-post test design involving 29 samples of elementary students at SDN Ploso I-172 Surabaya. The samples were chosen through a simple random sampling technique. The data were collected by interview using the questionnaire. The statistical test utilized the Paired Sample T-Test. The nutrition education with posters media increased the students' knowledge $(p=0.005)$ and attitude $(p<0.001)$ on a balanced diet after the intervention. Similarly, in the case of nutrition education using nutrition card, there was an increase in knowledge $(p=0.016)$ and attitude (0.002). The average students' knowledge before they got nutrition education with poster media was 9.40, which then increased to 11.00, while the average students' attitude score also increased from 71.47 to 78.20. The average students' knowledge before they were given nutrition education with nutrition card media was 8.86 and increased to 11.57, the average students' attitude value also increased from 72.21 to 79.28 . In conclusion, there were the effects of nutrition education intervention using poster and nutrition card in improving the knowledge and attitude on balance diet of elementary students at SDN Ploso I-172 Surabaya.
\end{abstract}

Keywords: obesity, nutrition card, knowledge, attitude

\begin{abstract}
ABSTRAK:
Prevalensi kegemukan pada anak di Indonesia meningkat dari tahun ke tahun. Hal tersebut disebabkan konsumsi makanan berlemak yang tinggi dan kurangnya pengetahuan mengenai gizi seimbang. Pemberian pendidikan kesehatan gizi seimbang (penyuluhan gizi) adalah Salah satu cara yang dapat digunakan untuk meningkatkan pengetahuan dan sikap sadar gizi serta mengurangi permasalahan gizi yang ada untuk menganalisis pengaruh pemberian pendidikan gizi dengan media poster dan kartu gizi terhadap pengetahuan dan sikap tentang gizi seimbang pada siswa di SDN Ploso I-172 Surabaya. Jenis penelitian ini adalah quasi eksperimental dengan menggunakan rancangan pre-post test design dengan besar sampel 29 siswa SDN Ploso I-172 Surabaya yang dipilih dengan menggunkan sampel acak sederhana (simple random sampling). Pengumpulan data dilakukan dengan cara wawancara menggunakan kuesioner. Uji statistik yang digunakan adalah Paired Sampel T-Test. Pendidikan gizi dengan media poster mengalami peningkatan pengetahuan $(p=0,005)$ dan sikap $(p<0,001)$ anak tentang gizi seimbang setelah diberikan intervensi. Begitu pula pendidikan gizi dengan media kartu gizi, terjadi peningktan pengetahuan $(p=0,002)$ dan sikap $(0,016)$. Rata-rata nilai pengetahuan sebelum pemberian pendidikan gizi dengan media poster adalah 9,40 dan meningkat menjadi 11,00 , rata-rata nilai sikap juga mengalami peningkatan dari 71,47 mnjadi 78,20 . Rata-rata nilai pengetahuan sebelum pemberian pendidikan gizi dengan media kartu gizi adalah 8,86 dan meningkat menjadi 11,57, rata-rata nilai sikap juga mengalami peningkatan dari 72,21 mnjadi 79,28. Terdapat pengaruh pemberian pendidikan gizi dengan media potser dan kartu gizi terhadap peningkatan pengetahuan dan sikap anak tentang gizi seimbang.
\end{abstract}

(C2019 IJPH. License doi: 10.20473/ijph.vl14il.2019.210-220 Received 3 October 2017, received in revised form 2 November 2017, Accepted 30 November 2017, Published online: December 2019 
Kata Kunci: obesitas, game kartu gizi, pengetahuan, sikap

\section{PENDAHULUAN}

Obesitas adalah kelebihan berat badan, akibat dari penimbunan lemak tubuh yang berlebihan. Setiap orang memerlukan lemak dalam tubuh untuk menyimpan energi, sebagai penyekat panas, penyerap guncangan dan fungsi lainnya. Rata-rata wanita memiliki lemak tubuh yang lebih banyak dibandingkan pria. Perbandingan yang normal antara lemak tubuh dengan berat badan adalah sekitar $25-30 \%$ pada wanita dan $18-23 \%$ pada pria (Nurrahman, 2013). Obesitas pada anak telah menjadi masalah yang serius di Indonesia. Berdasarkan data terbaru dari Riskesdas tahun 2013, secara nasional prevalensi kegemukan pada anak umur 5-12 tahun masih tinggi yaitu 18,8 persen, terdiri dari gemuk 10,8 persen dan sangat gemuk (obesitas) 8,8 persen (Badan Penelitian dan Pengembangan Kesehatan, 2013).

Provinsi Jawa Timur mengalami peningkatan prevalensi gizi lebih pada anak usia sekolah (6-12 tahun) pada tahun 2007 dan 2013 (Badan Penelitian dan Pengembangan Kesehatan, 2013). Berdasarkan data Riskesdas Tahun 2013 proporsi penduduk berumur lebih dari 10 tahun dengan perilaku konsumsi makanan berlemak, kolesterol dan makanan gorengan lebih dari satu kali dalam sehari secara nasional adalah 40,7\% dan lima provinsi tertinggi diatas nilai nasional salah satunya adalah Jawa Timur (49,5\%).

Prevalensi kejadian obesitas pada siswa di SD Negeri Ploso II-173 Surabaya sebanyak 2\% dan prevalensi gizi lebih adalah 18\%. Faktor yang menyebabkan kejadian kegemukan dan obesitas pada siswa adalah status sosial ekonomi orang tua, pemenuhan gizi yang berlebihan, faktor genetik dan aktivitas fisik (Yaqin, 2014). Prevalensi kegemukan yang lebih besar ditemukan oleh Rosyidah dan Andrias
(2015) di Sekolah Dasar Negeri Ploso I-172 Surabaya, yaitu $63,4 \%$ dengan prevalensi obesitas 34,6\% dan gizi lebih 28,8\%. Berdasarkan hasil studi pendahuluan yang dilakukan kepada seluruh siswa kelas V Sekolah Dasar pada 9 Maret 2017 di SDN Ploso I-172 Surabaya ditemukan bahwa 5 siswa atau $4.9 \%$ tergolong kurus, 19 siswa atau $18.8 \%$ tergolong gemuk dan 7 orang atau $6.9 \%$ orang tergolong obesitas.

Permasalahan obesitas tidak hanya masalah kelebihan berat badan, tetapi juga dapat menimbulkan berbagai gangguan kesehatan seperti diabetes tipe 2, tekanan darah tinggi, stroke, serangan jantung, gagal jantung, kanker (jenis kanker tertentu, misalnya kanker prostat dan kanker usus besar), batu kandung empedu dan batu kandung kemih, gout dan artritis gout, osteoartritis, tidur apneu (kegagalan untuk bernafas secara normal ketika sedang tidur, menyebabkan berkurangnya kadar oksigen dalam darah), sindroma Pickwickian (obesitas disertai wajah kemerahan, underventilasi dan ngantuk) (Nurrahman, 2013).

Dengan tingginya presentase masalah gizi yang terjadi pada anak usia sekolah, maka diperlukan adanya pendidikan gizi yang dapat meningkatkan pengetahuan anak tentang gizi seimbang agar masalah tersebut dapat dicegah. Munthofiah (2008) menyebutkan salah satu faktor yang dapat mempengaruhi status gizi adalah tingkat pengetahuan. Tingkat pengetahuan yang baik mempunyai kemungkinan 17 kali lebih besar untuk mempunyai status gizi yang baik. Alfyan (2010) juga menyebutkan bahwa terdapat hubungan antara pengetahuan gizi dengan status gizi anak sekolah. Pemberian pendidikan kesehatan gizi seimbang (penyuluhan gizi) adalah Salah satu cara yang dapat digunakan untuk meningkatkan pengetahuan dan sikap sadar gizi serta mengurangi permasalahan gizi yang ada. 
Pendidikan gizi adalah pemberian informasi mengenai gizi yang dapat meningkatkan pengetahuan anak dan diharapkan dapat merubah pola makan dan kebiasaan makan anak. Pemberian pendidikan gizi pada anak sekolah harus menggunakan cara dan metode yang tepat agar dapat menarik perhatian anak sehingga anak dapat dengan mudah menyerap informasi yang diberikan (Nuryanto dkk, 2014). Salah satu metode dan media yang sering digunakan adalah ceramah dengan menggunakan poster. Selain itu, terdapat metode dan media yang juga berpengaruh terhadap tingkat pengetahuan anak yaitu dengan permainan. Menurut Zaini (2015), bermain adalah salah satu metode pendekatan yang dapat berdampak baik dalam kegiatan pendidikan. Dengan bermain, anak dapat menemukan dan mempelajari hal-hal baru yang belum diketahui sebelumnya. Selain itu, anak juga dapat belajar berinteraksi dengan orang lain.

Berdasarkan teori perilaku terencana atau Theory of Palanned Behavior (TPB) yang disampaikan Ajzen (1991) bahwa manusia berperilaku dengan sadar dan mempertimbangan segala informasi yang didapatkan. Informasi tersebut akan mempengaruhi sikap, norma subjektif dan kontrol perilaku serta intensi manusia. Oleh karena itu, pemberian informasi berupa pendidikan gizi sangatlah penting dalam proses pembentukan perilaku manusia. Berdasarkan hasil penelitian Demitri, dkk (2015) ada pengaruh antara pemberian pendidikan gizi melalui game puzzle terhadap pengetahuan anak. Hasil penelitian PKM Pengabdian Masyarakat IPB pada tahun 2013 tentang Permainan Edukatif (Nutriroll) Pengenalan Gizi Seimbang Untuk Anak Sekolah Dasar selama tiga bulan, juga terdapat pengaruh antara pemberian permainan edukatif terhadap pengetahuan anak. Selain itu menurut Tuzzahroh (2015) pendidikan gizi melalui media video, poster dan kwartet selama satu bulan berpengaruh terhadap pengetahuan anak. Berdasarkan uraian tersebut peneliti tertarik melakukan penelitian dengan metode dan media permainan yang baru yaitu game kartu gizi. Melalui game ini diharapkan anak lebih mudah menyerap informasi yang diberikan sehingga dapat meningkatkan pengetahuan anak dan akan berpengaruh terhadap sikap anak untuk melakukan kebiasaan dan pola makan yang baik.

\section{METODE PENELITIAN}

Jenis penelitian ini adalah quasi eksperimental atau eksperimen semu dengan menggunakan rancangan pre-post test design. Penelitian dilakukan di SDN Ploso I172 Surabaya pada bulan Juni-Juli 2017 dengan melakukan 4 kali intervensi. Subyek dalam penelitian ini adalah siswa siswi kelas V SDN Ploso I-172 Surabaya. Cara pemilihan sampel yang digunakan dalam penelitian ini adalah sampel acak sederhana (simple random sampling), dengan jumlah sampel 29 responden. 15 responden merupakan kelompok kontrol dan 14 responden adalah kelompok perlakuan. Pengumpulan data didapatkan dengan cara wawancara dengan menggunakan kuesioner. Media yang digunakan dalam penelitian ini adalah poster untuk kelompok kontrol dan kartu gizi untuk kelompok perlakuan.

Variabel bebas pada penelitian ini adalah pemberian pendidikan gizi dengan media poster dan kartu gizi, sedangkan variabel terikatnya adalah pengetahuan dan sikap anak. Tingkat pengetahuan dikelompokkan menjadi 3 yaitu kurang, sedang dan baik (Khomsan, 2000). Sikap dikelompokkan menjadi 5 yaitu tidak baik, kurang baik, cukup, baik dan sangat baik (Narimawati, 2008). Data dasar yang diambil dalam penelitian ini adalah karakteristik anak yang meliputi umur dan jenis kelamin anak dan karakteristik Ibu yang terdiri dari pekerjaan dan pendidikan terakhir ibu. Analisis data dalam penelitian 
ini terdiri dari analisis univariat dan analisis bivariat. Analisis univariat digunakan untuk menggambarkan distribusi frekuensi dari data dasar dan variabel yang diteliti. Analisis bivariat digunakan untuk mengetahui pengaruh antara variabel bebas dan variabel terikat. Analisis bivariat pada penelitian ini menggunakan Uji Paired Sampel T-Test. Materi pendidikan gizi yang akan diberikan adalah Gizi Seimbang, Triguna Makanan, Empat Pilar Gizi seimbang dan 10 Pedoman Umum gizi Seimbang. Game kartu gizi dilakukan oleh 3-5 orang pemain, cara bermainnya adalah mengumpulkan kartu yang berisi bahan makanan pada anjuran piring makanku, yaitu makanan pokok, lauk hewani, lauk nabati, sayur dan buah. Setiap pemain diberikan lima kartu secara acak pada awal permainan, sisa kartu diletakkan di tengah para pemain, lalu dengan bergantian pemain mengambil kartu yang ada ditengah untuk menukar kartu yang tidak diinginkan dan membuang kartu tersebut ke pemain berikutnya. Pemain berikutnya memiliki hak untuk mengambil kartu buangan dari pemain sebelumnya atau mengambil kartu ditengah (pilih salah satu), begitu pula pemain berikutnya, sampai salah satu dari pemain memiliki lima kartu lengkap yang berisi makanan pokok, lauk hewani, lauk nabati, sayur dan buah. Penelitian ini telah memperoleh keterangan lolos kaji etik dari Komisi Etik FKM No : 109-KEPK.

\section{HASIL}

\section{Karakteristik Responden}

Sampel pada penelitian adalah siswasiswi kelas V SDN Ploso I-172 Surabaya yang sesuai dengan kriteria inklusi dan eksklusi. Karakteristik responden dalam penelitian ini terdiri dari karakteristik anak yang meliputi umur, jenis kelamin dan urutan anak dalam keluarga dan karakteristik Ibu yang meliputi pekerjaan ibu dan pendidikan terakhir ibu., tersaji dalam Tabel 1 .

Jumlah responden pada penelitian ini adalah 29 siswa. 15 siswa masuk dalam kelompok kontrol dan 14 siswa masuk daam kelompok perlakuan. Pada kelompok kontrol dan kelompok perlakuan rata-rata berusia 11-12 tahun. Hal tersebut dikarenakan usia tersebut adalah usia yang tepat untuk anak sekolah yang duduk di bangku kelas V Sekolah Dasar apabila mengacu pada Keputusan Menteri Pendidikan Nasional RI (2002) bahwa syarat usia diterimanya anak di Sekolah Dasar adalah 7 tahun, maka pada saat anak sudah duduk di bangku kelas V SD usia mereka adalah 11-12 Tahun. Berdasarkan data siswa di Sekolah Dasar Negeri Ploso I-172 Surabaya, diketahui bahwa jumlah siswa yang berjenis kelamin perempuan lebih besar dari pada laki-laki. Keluarga responden kebanyakan adalah keluarga muda yang masih memiliki 1 atau 2 orang anak saja

Surabaya merupakan salah satu kota industri terbesar di Indonesia. Pembangunan dibidang industri mencakup pembangunan industri rumah tangga, industri kecil dan industri menengah. Perkembangan industri tersebut ditandai dengan berdirinya pabrikpabrik di kota Surabaya. Semakin banyak pabrik berdiri maka semakin banyak tenaga kerja yang diserap (Julianto, 2016). Sebagian besar ibu responden bekerja sebagai karyawan swasta baik di industri kecil maupun industri besar. Pekerjaan adalah faktor yang dapat mempengaruhi pengetahuan apabila dilihat dari jenis pekerjaan dan intensitas interaksi dengan orang lain. Orang yang lebih banyak berinteraksi dengan orang lain akan lebih banyak mendapatkan pengetahuan baru (Notoadmojo, 2003). Kemudahan memperoleh informasi dapat mempercepat seseorang memperoleh pengetahuan dan informasi yang baru dan dapat menggantikan ataupun menyempurnakan informasi sebelumnya (Yusniar, 2013). 
Tingkat pendidikan ibu responden tergolong baik. Tingkat pendidikan ibu dapat mempengaruhi tingkat pengetahuan tentang gizi, semakin tinggi pendidikan ibu maka akan semakin tinggi pula kesadaran terhadap pentingnya kesehatan dalam keluarga (Octaviani dan Margawati, 2012). Selain itu menurut Hariyadi dan Ekayani (2011) bahwa pendidikan kesehatan adalah satu hal yang penting dan diperlukan untuk membentuk perilaku positif dalam hal memenuhi kebutuhan gizi sebagai salah satu unsur penting untuk mendukung status kesehatan seseorang.

Tabel 1. Karakterstik Responden

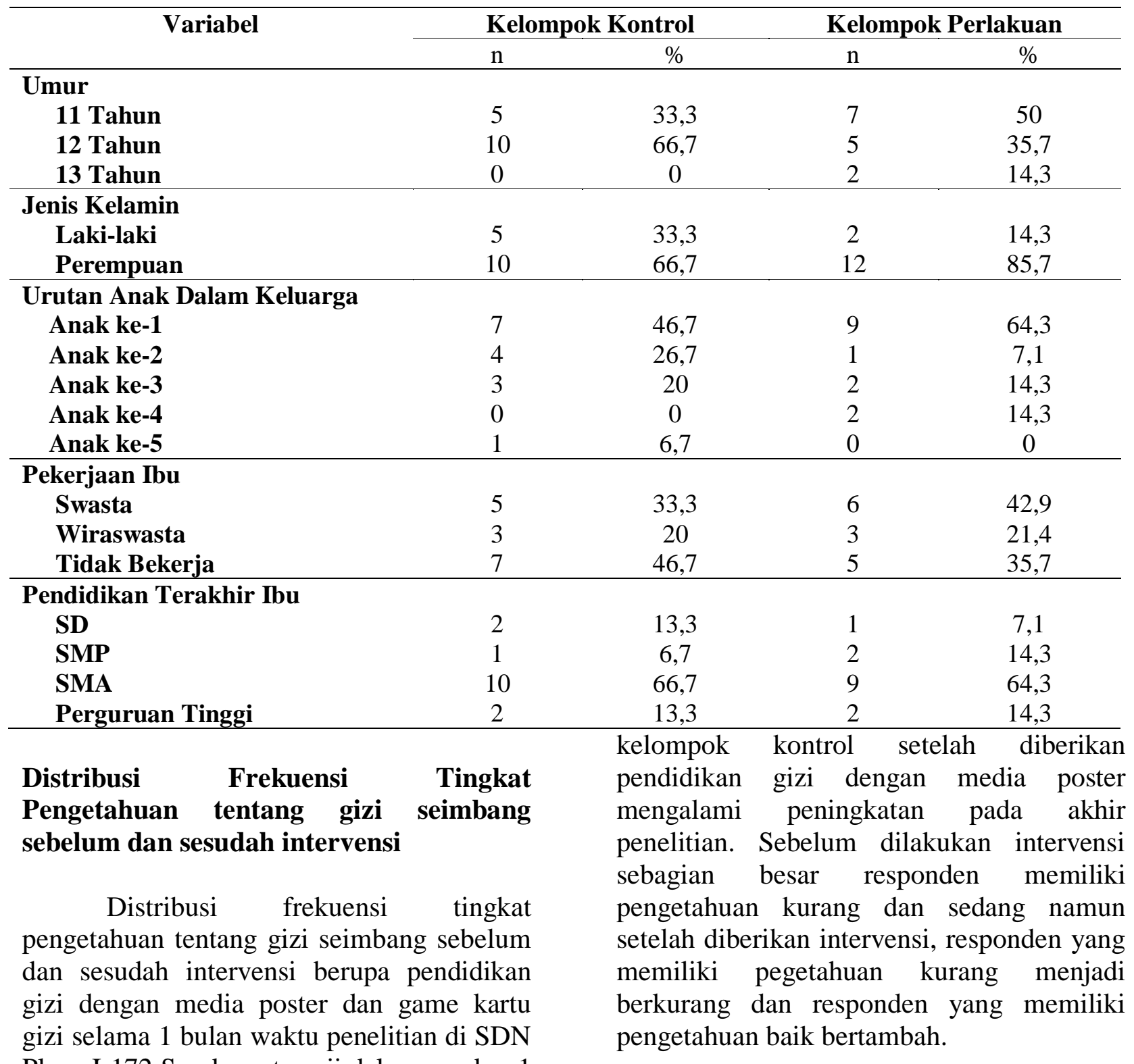

Ploso I-172 Surabaya tersaji dalam gambar 1 dan gambar 2. Berdasarkan gambar 1. dapat diketahui bahwa hasil penelitian pada 


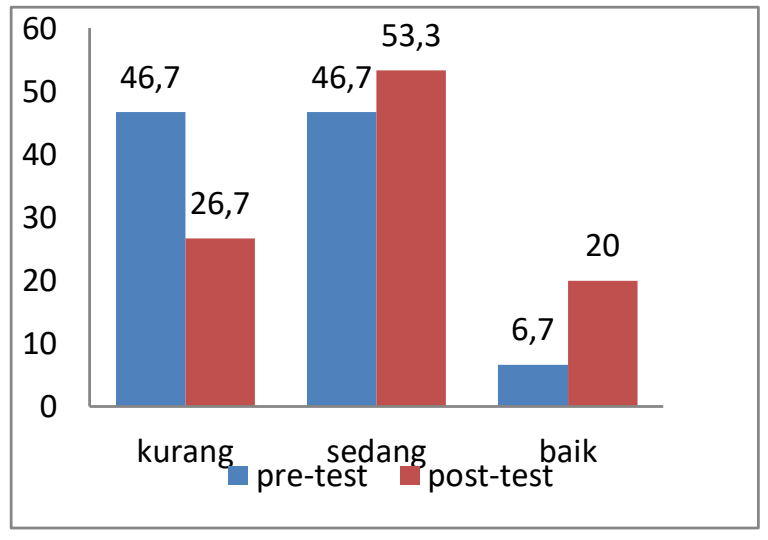

Gambar 1. Distribusi frekuensi pengetahuan tentang gizi seimbang sebelum dan sesudah dilakukan pendidikan gizi dengan media poster

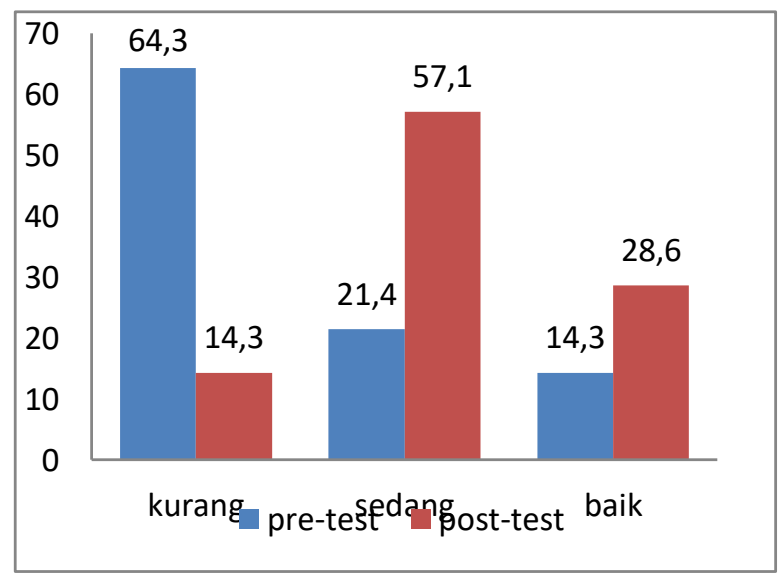

Gambar 2. Distribusi frekuensi pengetahuan tentang gizi seimbang sebelum dan sesudah dilakukan pendidikan gizi dengan media kartu gizi

Gambar 3 menunjukkan bahwa hasil penelitian pada kelompok kontrol setelah diberikan pendidikan gizi dengan media poster mengalami peningkatan pada akhir penelitian. Sebelum dilakukan intervensi rata-rata nilai sikap pada keompok kotrol adalah 71,47 dan meningkat menjadi 78,20 setelah dilakukan intervensi. Terjadi peningkatan sebesar 6,73 poin. Peningkatan sikap yang terjadi pada responden adalah tentang sarapan dan aktivitas fisik.

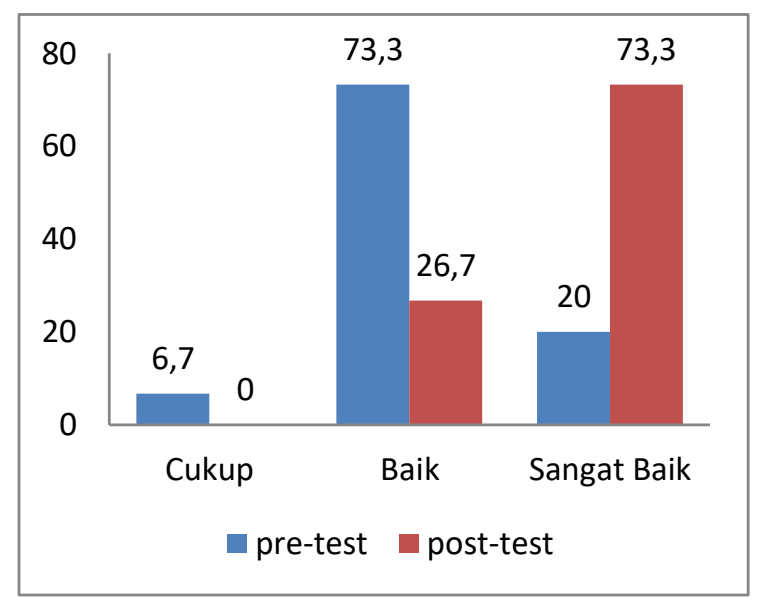

Gambar 3. Distribusi frekuensi sikap tentang gizi seimbang sebelum dan sesudah dilakukan pendidikan gizi dengan media poster

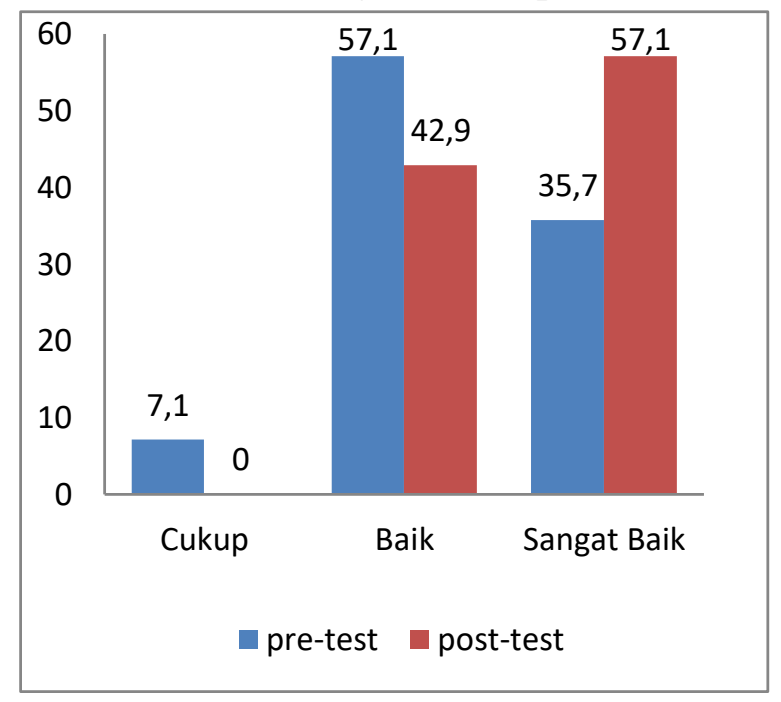

Gambar 4. Distribusi frekuensi sikap tentang gizi seimbang sebelum dan sesudah dilakukan pendidikan gizi dengan media poster

Setelah dilakukan intervensi Responden mampu menyebutkan sumber makanan apa saja yang terdapat dalam anjuran piring makanku. Responden dapat menyebutkan 3 kelompok zat gizi berdasarkan fungsinya beserta contoh makanannya. Responden juga mampu menyebutkan hal penting apa saja yang terdapat dalam tumpeng gizi seimbang. 
Berdasarkan Gambar 2. dapat diketahui bahwa hasil penelitian pada kelompok perlakuan setelah diberikan pendidikan gizi dengan media kartu gizi mengalami peningkatan pada akhir penelitian. Sebelum dilakukan intervensi sebagian besar responden memiliki pengetahuan kurang namun setelah diberikan intervensi, responden dengan kategori kurang menurun. Peningkatan pengetahuan ini dikarenakan responden mampu menyebutkan pedoman gizi seimbang dengan benar, mampu menyebutkan empat pilar gizi seimbang dan mampu menyebutkan hal penting apa saja yang terdapat dalam tumpeng gizi seimbang.

\section{Distribusi Frekuensi Sikap tentang gizi seimbang sebelum dan sesudah intervensi}

Distribusi frekuensi sikap tentang gizi seimbang sebelum dan sesudah intervensi berupa pendidikan gizi dengan media poster dan game kartu gizi selama 1 bulan waktu penelitian di Sekolah Dasar Negeri Ploso I-172 Surabaya tersaji dalam Gambar 3 dan Gambar 4. Gambar 4 menunjukkan bahwa hasil penelitian pada kelompok perlakuan setelah diberikan pendidikan gizi dengan media poster mengalami peningkatan pada akhir penelitian. Sebelum dilakukan intervensi rata-rata nilai sikap pada keompok kotrol adalah 72,21 dan meningkat menjadi 79,28 setelah dilakukan intervensi. Terjadi peningkatan sebesar 7,07 poin. Peningkatan sikap yang terjadi pada responden adalah tentang sarapan, aktivitas fisik, empat pilar gizi seimbang dan 10 pedoman umum gizi seimbang.

\section{Pengaruh Pendidikan Gizi terhadap Peningkatan Pengetahuan dan Sikap Sebelum dan Sesudah intervensi}

Uji statistik dengan menggunakan uji Paired Sampel T-Test untuk menguji pengetahuan dan sikap tersaji dalam tabel 2 .
Berdasarkan tabel 2. didapatkan hasil bahwa ada perbedaan antara pretest dan post test pengetahuan pada kelompok kontrol maupun kelompok perlakuan yang artinya ada pengaruh pemberian pendidikan gizi dengan media poster pada kelompok kontrol $(p=0,005)$ dan media kartu gizi pada kelompok perlakuan $(p=0,002)$ terhadap tingkat pengetahuan anak tentang gizi seimbang di SDN Ploso I-172 Surabaya.

Dari tabel tersebut juga didapatkan hasil bahwa ada perbedaan antara pretest dan posttest sikap pada kelompok kontrol maupun kelompok perlakuan yang artinya ada pengaruh pemberian pendidikan gizi dengan media poster pada kelompok kontrol $(p<0,001)$ dan media kartu gizi pada kelompok perlakuan $(p=0,016)$ terhadap sikap anak tentang gizi seimbang di SDN Ploso I-172 Surabaya.

Tabel 2. Pengaruh Pemberian Pendidikan Gizi terhadap Peningkatan Pengetahuan dan Sikap

\begin{tabular}{ccccc}
\hline Variabel & \multicolumn{2}{c}{$\begin{array}{c}\text { Kelompok } \\
\text { Kontrol }\end{array}$} & \multicolumn{2}{c}{$\begin{array}{c}\text { Kelompok } \\
\text { Perlakuan }\end{array}$} \\
\cline { 2 - 5 } & $\begin{array}{c}\text { Pre- } \\
\text { test }\end{array}$ & $\begin{array}{c}\text { Post- } \\
\text { test }\end{array}$ & $\begin{array}{c}\text { Pre- } \\
\text { test }\end{array}$ & $\begin{array}{c}\text { Post- } \\
\text { test }\end{array}$ \\
\hline Pengetahuan & & & & \\
Mean & 9,40 & 11 & 8,86 & 11,57 \\
SD & 2,29 & 1,96 & 2,54 & 1,95 \\
p-value & 0,005 & 0,005 & 0,002 & 0,002
\end{tabular}

\begin{tabular}{lcccc}
\hline Sikap & & & & \\
Mean & 71,47 & 78,20 & 72,21 & 79,28 \\
SD & 6,78 & 5,39 & 7,20 & 5,22 \\
p-value & 0,000 & 0,000 & 0,016 & 0,016
\end{tabular}

\section{PEMBAHASAN}

Pengetahuan adalah hasil dari tahu, hasil tersebut didapatkan dari hasil penginderaan terhadap objek tertentu. Sebagian besar pengetahuan manusia 
didapatkan dari mata dan telinga (Notoadmojo, 2007). Tingkat pengetahuan seseorang tentang gizi dapat mempengaruhi sikap dan perilaku dalam hidup sehat, contohnya adalah dapat memilih makanan yang baik, dapat memahami manfaat suatu bahan makanan dan mengenal manfaat kandungan gizi yang ada dalam makanan tersebut (Azwar, 2011). Menurut Wawan (2010), ada 2 faktor yang dapat mempengaruhi pengetahuan seseorang, yaitu faktor internal dan faktor eksternal. Faktor internal adalah faktor yang berasal dalam diri manusia itu sendiri yaitu pendidikan, pekerjaan, dan umur, sedangkan faktor eksternal adalah faktor yang berasal dari luar yaitu lingkungan dan sosial budaya.

Berdasarkan hasil penelitian didapatkan bahwa pada kelompok kontrol pengetahuan responden mengalami peningkatan setelah diberikan pendidikan gizi dengan media poster, begitu pula pada kelompok perlakuan, terjadi peningkatan pengetahuan setelah diberikan pendidikan gizi dengan media kartu gizi. Peningkatan pengetahuan pada kelompok kontrol dan kelompok perlakuan dalam kategori baik adalah sama. Hal tersebut menunjukkan bahwa pemberian pendidikan gizi dengan media poster maupun kartu gizi efektif meningkatkan pengetahuan gizi pada responden. Akan tetapi pendidikan gizi dengan media kartu gizi memiliki nilai peningkatan pengetahuan yang lebih tinggi. Hal ini dikarenakan pendidikan gizi tersebut mengunakan metode dan media yang tepat bagi responden, sehingga responden dapat menerima materi yang diberikan dengan baik. Seperti yang telah disampaikan oleh Tuzzahroh (2015) bahwa faktor-faktor yang dapat mempengaruhi peningkatan pengetahuan pada proses penyuluhan adalah metode, media dan waktu penyuluhan yang diterapkan. Siregar dan Sondang (2014) juga menyampaikan bahwa pesan visual berupa gambar lebih mudah tertanam dalam pikiran audience dibandingkan dengan kata-kata, sehingga penyuluhan kesehatan dapat lebih efektif jika menggunakan media yang lebih banyak menampilkan gambar, terlebih pada sasaran audience siswa sekolah dasar.

Pengetahuan gizi memiliki peranan penting dalam pembentukan kebiasaan atau makan seseorang karena hal tersebut akan mempengaruhi seseorang dalam memilih makanan jenis dan jumlah makanan yang akan dimakan. Seseorang yang memiliki pengetahuan gizi yang baik akan memperhatikan keadaan gizi setiap makanan yang dimakan (Almatsier, 2011). Tingkat pengetahuan seseorang tentang gizi dapat mempengaruhi sikap dan perilaku dalam hidup sehat, contohnya adalah dapat memilih makanan yang baik, dapat memahami manfaat suatu bahan makanan dan mengenal manfaat kandungan gizi yang ada dalam makanan tersebut. Pengetahuan gizi diharapkan dapat mempengaruhi konsumsi makanan seseorang sehingga akan berdampak pada status gizi orang tersebut (Azwar, 2003).

Sikap merupakan perbuatan yang berasal dari suatu keyakinan atau kecenderungan terhadap objek tertentu, kecenderungan ini bukan merupakan pembawaan atau keturunan, akan tetapi adalah hasil dari proses belajar. Sikap adalah salah satu faktor yang dapat mempengaruhi perilaku seseorang (Ajzen, 1991). Menurut Notoadmojo (2003), sikap dapat dipelajari dan sikap juga dapat berubah pada keadaan tertentu. Menurut Azwar (2011) ada beberapa faktor yang dapat mempengaruhi sikap yaitu, pengalaman pribadi, pengaruh orang lain yang dianggap penting, pengaruh kebudayaan, informasi atau media massa, lembaga pendidikan dan lembaga agama yang menyampaikan pendidikan tersebut, dan faktor emosional dari responden.

Berdasarkan hasil penelitian didapatkan bahwa kelompok kontrol dan kelompok perlakuan mengalami peningkatan setelah diberikan intervensi. Pada kelompok kontrol, sebelum diberikan pendidikan gizi 
dengan media poster rata-rata nilai sikap responden adalah 71,4 , setelah diberikan pendidikan gizi rata-rata nilai sikap meningkat menjadi 78,2. Pada kelompok perlakuan, sebelum diberikan pendidikan gizi dengan media kartu gizi rata-rata nilai sikap responden adalah 72,2 setelah diberikan pendidikan gizi rata-rata nilai sikap meningkat menjadi 79,2. Hal tersebut menunjukkan bahwa pemberian pendidikan gizi dengan media poster maupun kartu gizi efektif meningkatkan sikap pada responden. Akan tetapi pemberian pendidikan gizi dengan media kartu gizi memiliki peningkatan nilai sikap yang lebih tinggi karena peningkatan nilai responden dapat dipengaruhi oleh peningkatan pengetahuan yang juga dialami responden. Pengetahuan gizi responden yang meningkat akan membantu sikap responden dan akan mempengaruhi kebiasan responden dalam memilih makanan yang sehat. Seperti yang dikataan oleh Notoatmodjo (2007) bahwa komponen pengetahuan merupakan salah satu faktor yang menentukan sikap.

Menurut Merdhika, dkk (2014) terdapat pengaruh penyuluhan terhadap tingkat pengetahuan ibu menyusui dalam pemberian ASI Eksklusif dan terdapat pengaruh penyuluhan terhadap sikap ibu menyusui dalam pemberian ASI Eksklusif. Sedangakan menurut Azzahrah, dkk (2015) ada perbedaan tingkat pengetahuan Ibu tentang pemberian MP-ASI sebelum dan sesudah diberikan pendidikan gizi berupa konseling, begitu pula dengan sikap Ibu tentang pemberian MP-ASI yang mengalami peningkatan sebelum dan sesudah diberikan konseling tentang MP-ASI. Hal tersebut juga dibuktikan dalam penelitian yang dilakukan oleh Nuryanto, dkk (2014) bahwa pendidikan yang diberikan dapat mempengaruhi pengetahuan dan sikap anak tentang gizi.

Berdasarkan hasil penelitian setelah dilakukan uji statistika menggunakan uji Paired t-test didapatkan hasil bahwa pemberian pendidikan gizi dengan media poster ataupun media kartu gizi dapat berpengaruh terhadap peningkatan pengetahuan respoden. Seperti yang telah disampaikan oleh Yustisa (2003) bahwa terdapat pengaruh penggunaan poster dalam promosi kesehatan terhadap peningkatan pengetahuan siswa sekolah dasar. Siregar dan Sondang (2014) juga mengatakan bahwa Poster efektif meningkatkan pengetahuan anak tentang kebersihan gigi di SDN Tanjung Selamat Kecamatan Sunggal Kota Medan. Selain itu, pemberian pendidikan gizi dengan metode dan permainan juga berpengaruh terhadap pengetahuan anak, seperti yang disampaikan oleh Dhemitri (2014) bahwa peningkatan pengetahuan anak sekolah tentang pola makan seimbang dapat meningkat dengan pemberian pendidikan gizi melalui game puzzle. Sebelum dilakukan pendidikan gizi, pengetahuan anak yang masuk dalam kategori kurang adalah $26.7 \%$, namun setelah dilakukan pendidikan gizi, tidak ada lagi yang masuk dalam kategori kurang. Hal tersebut sejalan dengan penelitian yang dlakukan PKM Pengabdian Masyarakat IPB bahwa terdapat peningkatan pengetahuan anak tentang gizi seimbang setelah diberikan permainan edukatif NutriRoll selama 3 bulan penelitian.

Bedasarkan hasil penelitian setelah dilakukan uji statistika menggunakan uji Paired t-test didapatkan hasil bahwa pemberian pendidikan gizi dengan media poster ataupun media kartu gizi dapat berpengaruh terhadap peningkatan sikap responden. Menurut Rachmawati (2014) pada penelitiannya yang berjudul pengaruh pemberian penyuluhan gizi terhadap pengetahuan gizi dan sikap hidup sehat remaja di SMAN 2 Sidoarjo, menyebutkan bahwa pemberian penyuluhan materi gizi dan hidup sehat berpengaruh terhadap sikap hidup sehat pada remaja di SMAN 2 Sidoarjo. Norviatin (2016) juga menyebutkan bahwa tingkat pengetahuan, perilaku dan sikap ibu tentang diare pada 
balita mengalami perubahan yang signifikan setelah diberikan penyuluhan tentang kesehatan.

\section{SIMPULAN}

Terdapat pengaruh pemberian 4 sesi pendidikan gzi dengan media poster dan kartu gizi terhadap peningkatan pengetahuan dan sikap anak tentang gizi seimbang yang dilakukan selama satu bulan penelitian. Oleh karena itu diperlukan pemberian pendidikan gizi secara berkelanjutan dengan media poster dan kartu gizi agar dapat menjadi kebiasaan yang baik dan bermanfaat untuk kesehatan.

\section{DAFTAR PUSTAKA}

Ajzen, I. 1991. The Theory of Planned Behavior. Organizational Behavior and Human Decision Processes 50, 179-121 (1991). University of Massachusetts at Amberst. [https://doi.org/10.1016/07495978(91)90020-T]

Alfyan, MT. 2010. Hubungan Pengetahuan Gizi dengan Status Gizi Siswa di SMA Harapan 1 Medan. Skripsi. Universitas Sumatera Utara.

Azwar, S. 2011. Sikap Manusia Teori dan Pengukurannya. Pustaka Pelajar. Yogyakarta.

Azzahrah, Fatimah dan Lailatul Muniroh.2015. Pengaruh Konseling terhadap Pengetahuan dan Sikap Pemberian MPASI. Universitas Airlangga. Surabaya.

Badan Penelitian dan Pengembangan Kesehatan. 2013. Riset Kesehatan Dasar (Riskesdas) 2013: Laporan Nasional. Jakarta: Kementerian Kesehatan RI.

Demitri, A., Nasution, E., Aritonang, E. 2015. Pengaruh Pendidikan Gizi Tentang Pola Makan Seimbang Melalui Game Puzzle Terhadap Peningkatan Pengetahuan Anak SDN 067690 Kota Medan. Jurnal Gizi, Kesehatan Reproduksi dan Epidemiologi Vol 1, No.2 (2015).

Hariyadi, D., dan Ekayani, I. 2011. Analisis Pengaruh Perilaku Keluarga Sadar Gizi terhadap Stunting di Propinsi Kalimantan Barat. Jurnal Teknologi dan Kejuruan vol. 34 no. 1 Pebruari 2011 hal. 71-80.

Julianto, F.T. 2016. Analisis Pengaruh Jumlah Industri Besar dan Upah Minimum terhadap Pertumbuhan Ekonomi di Kota Surabaya. Jurnal Ekonomi dan Bisnis Hal 229-256 Volume 1, Nomor 2, September 2016.

Kementerian Pendidikan RI. 2002. Keputusan Menteri Pendidikan Nasional RI tentang Penerimaan Siswa pada Taman Kanakkanak dan Sekolah. Jakarta: Kementerian Pendidikan RI.

Khomsan. 2000. Teknik Pengukuran Pengetahuan Gizi. Fakultas Ekologi Manusia Institut Pertanian Bogor.Bogor.

Merdhika, Widha Ayu Rima, Mardji dan Mazarina Devi. 2014. Pengaruh Penyuluhan ASI Ekslusif terhadap Pengetahuan Ibu Tentang ASI Eksklusif di Kecamatan Kanigoro Kabupaten Blitar. Jurnal Teknologi dan Kejuruan, Vol 37, No. 1, Pebruari 2014:65-72.

Munthofiah, Siti. 2008. Hubungan antara Pengetahuan, Sikap dan Perilaku Ibu dengan Status Gizi Anak Balita. Tesis. Universitas Sebelas Maret Surakarta.

Narimawati, U. 2008. Metodologi Penelitian Kualitatif dan Kuantitatif, Teori dan Aplikasi. Bandung: Agung Media.

Norviatin, Dini. 2016. Pengaruh Penyuluhan dan Pemberian Leaflet terhadap Peningkatan Pengetahuan, Perilaku dan Sikap ibu tentang Diare pada Balita di Puskesmas Maja Kabupaten Majalengka. Universitas Swadaya Gunung Jati Cirebon.

Notoadmojo, S. 2003. Pendidikan dan Perilaku Kesehatan.PT Rineka Cipta. Jakarta.

Notoadmojo, S. 2007. Perilaku Kesehatan dan Ilmu Perilaku.PT Rineka Cipta. Jakarta.

Nurrahman. 2013. Obesitas Di Kalangan AnakAnak dan Dampaknya terhadap Penyakit Kardiovaskular. Skripsi. Universitas Muhammadiyah Semarang.

Nuryanto, A.P., Puruhita, N., dan Muis, S.F. 2014. Pengaruh Pendidikan Gizi Terhadap Pengetahuan dan Sikap Tentang Gizi Anak Sekolah Dasar. 
Jurnal Gizi Indonesia (ISSN : 18584942).

Octaviani, I.A., dan Margawati, A., 2012. Hubungan Pengetahuan dan Perilaku Ibu Buruh Pabrik tentang KADARZI (Keluarga Sadar Gizi) dengan Status Gizi Anak Balita (Studi di Kelurahan Pagersari, Ungaran). Journal of Nutrition College vol. 1 no. 1 Tahun 2012 hal. 46-54.

PKM Pengabdian Masyarakat. 2013. Nutri-Roll Permainan Edukatif Pengenalan Gizi Seimbang Untuk Anak Sekah Dasar. Institut Pertanian Bogor.

Pratiwi, DA., Yuniar, N. dan Erawan, PEM. 2015. Pengaruh Penyuluhan Metode Permainan Edukatif dan Metode Ceramah Terhadap Pengetahuan, Sikap dan Tindakan tentang Pencegahan Penyakit Diare pada Murid SD di Kecamatan Poasia Kota Kendari Tahun 2015. Skripsi. Universitas Halu Oleo.

Rachmawati, Melsandi. 2014. Pengaruh Pemberian Penyuluhan Gizi terhadap Pengetahuan Gizi dan Sikap Hidup Sehat Remaja di Sekolah Menengah Atas Negeri 2 Sidoarjo. Ejournal boga, Vol 3(3): 31-35. Universitas Negeri Surabaya.

Rosyidah, Zia dan Dini Ririn Andrias (2015). Jumlah Uang Saku dan Kebiasaan Melewatkan Sarapan Berhubungan dengan Status Gizi Lebih Anak Sekolah Dasar. Jurnal Media Gizi Indonesia, Vol 10, No. 1 Januari-Juni 2015: hlm 1-6.

Safitri, CH., Wilujeng, CS dan Handayani, D. 2014. Perbedaan Metode Team Game Tournament dan Ceramah Terhadap Peningkatan Pengetahuan Pemilihan Jajanan Sehat. Indonesian Journal of Human Nutrition, Desember 2014, Vol. 1 No. 2: 89-105.

Siregar, R dan Sondang. 2014. Efektifitas Penyuluhan dengan Media Poster terhadap Peningkatan Pengetahuan tentang Kebersihan Gigi pada Siswa/I Kelas III dan IV di SDN 104186 Tanjung Selamat Kecamatan Sunggal Tahun 2014. Jurnal Imliah PANNMED Vol. 9 No. 2 September Desember 2014.
Sukma, DC. dan Margawati, A. 2014. Hubungan Pengetahuan dan Sikap dala Memilih Makanan Jajajanan dengan Obestas pada Remaja di SMP Negeri 2 Brebes. Journal of Nutrition College, Volume 3(4):

862-870. [https://doi.org/10.14710/jnc.v3i4.6892 ]

Tuzzahroh, F. 2015. Pengaruh Penyuluhan Gizi Seimbang dengan Media Video, Poster dan Permainan Kwartet Gizi Terhadap Pengetahuan Gizi dan Status Gizi Siswa di Sekolah Dasar Negeri Karangasem III Kota Surakarta. Skripsi. Universitas Muhammadiyah Surakarta.

Wawan, A. 2010.Teori dan Pengukuran Pengetahuan, Sikap dan Perilaku Manusia.Nuha Medika. Yogyakarta.

Yaqin, MK. 2014. Prevalensi Obesitas pada Anak Usia SD Menurut IMT/U di SD Negeri Ploso II No 173 Surabaya. Universitas Negeri Surabaya. Surabaya.

Yusniar. 2013. Hubungan Informasi dan Pendidkan dengan Pengetahuan Bidan tentang Hypnobirthing di Puskesmas Krueng Mane Kabupaten Aceh Utara. Karya Tulis Ilmiah. STIKES U'Budiyah. Banda Aceh.

Zaini, A. 2015. Bermain Sebagai Metode Pembelajaran Bagi Anak Usia Dini. Jurnal Thufula Volume:3 No:1. STAIN Kudus. 